\title{
PLASMA LEVELS OF CORTISOL IN MAN DURING SPINAL ANAESTHESIA AND SURGERY
}

\author{
Tsutomu Oyama, M.D., AND A. Matsuki, M.D. ${ }^{*}$
}

IT is WELL ESTABLISHED that general anaesthesia, depending upon the agent used, may or may not be associated with elevation of plasma levels of cortisol prior to the start of surgery. Ether and halothane anaesthesia, for instance, are usually accompanied by an increase in plasma cortisol, while methoxyflurane, neuroleptic anaesthesia, and thiopental anaesthesia are not. ${ }^{1-9}$ Spinal anaesthesia, on the other hand, has been considered not to be usually associated with any significant increase in plasma cortisol levels. ${ }^{1-4}$

However, knowledge of the effect of spinal anaesthesia alone on adrenocortical function is incomplete and inconclusive at the present time, owing to the small number of patients studied. For example, Sandberg, ${ }^{1}$ Virtue, ${ }^{2}$ and Hammond ${ }^{3}$ and their colleagues studied it in four, ten, and seven patients respectively. The present study, therefore, was undertaken to investigate the effect of spinal anaesthesia alone on the plasma cortisol levels in 40 surgical patients. An additional seven patients served as a control group, and the results in them were compared with the effects of anaesthesia plus surgery.

\section{METHOD}

Forty-seven patients ranging in age from 16 to 62 years were the subjects of the study. All patients underwent elective operations as shown in Tables I and II, except the seven patients who served as controls, and no patient was included who had hepatic, renal, endocrinological, or cardiovascular disease. Five hundred millilitres of five per cent dextrose in water were infused during the entire procedure and blood loss over $500 \mathrm{ml}$ was replaced by transfusion.

No patients received premedication. Hyperbaric spinal anaesthesia was performed at 1-3 PM. The spinal puncture was made at $\mathrm{L} 3-4$ or $\mathrm{L} 4-5$ with a \#20 or \#21 needle in the right lateral position. The new short-acting local anaesthetic agent, quatacain (Tanacaine), 2-methyl-2-n-propylaminopropion-0-toluide hydrochloride, $200 \mathrm{mg}$ diluted in $6.7 \mathrm{ml} 10$ per cent glucose (a 3 per cent solution with a specific gravity $1040 \pm 3$ ) was employed for 20 patients. Lidocaine (Xylocaine 3 per cent solution, specific gravity $1030 \pm 3$ ) was used for 20 patients (Fig. 1). No epinephrine was added to these agents.

The doses, level of analgesia, duration of analgesia and surgery, and the type of surgery are shown in Tables I and II. The average doses of quatacain and lidocaine were $2.6 \pm 0.06 \mathrm{ml}$ ( $\pm=$ standard error of the mean) and $2.6 \pm 0.08$ $\mathrm{ml}$ respectively. The mean duration of analgesia in the quatacain and lidocaine Japan.

-Department of Anesthesia, Hirosaki University School of Medicine, Hirosaki, Aomori-Ken, 
TABLE I

Patients and Operations for Spinal Anaesthesia with Quatacain (Tanacaine)

\begin{tabular}{|c|c|c|c|c|c|c|}
\hline $\begin{array}{c}\text { Patient } \\
\text { no. }\end{array}$ & Age & Operation & $\begin{array}{c}\text { Operative } \\
\text { time } \\
\text { (min) }\end{array}$ & $\begin{array}{c}\text { Duration } \\
\text { of analgesia } \\
\text { (min) }\end{array}$ & $\begin{array}{c}\text { Level } \\
\text { (T) }\end{array}$ & Dose \\
\hline 1 & 26 & Caesarean section & 50 & $2: 20$ & 4 & 2.5 \\
\hline 2 & 26 & Caesarean section & 48 & $1: 40$ & 5 & 2.2 \\
\hline$\overline{3}$ & 59 & T.U.R. & 20 & $1: 10$ & 12 & 3.0 \\
\hline 4 & 19 & Haemorrhoidectomy & 15 & $1: 30$ & 11 & 2.0 \\
\hline 5 & 62 & Herniorrhaphy & $1: 05$ & $1: 50$ & 5 & 2.5 \\
\hline 6 & 33 & Appendectorny & 25 & $1: 20$ & 6 & 2.4 \\
\hline 7 & 21 & Appendectomy & 23 & $1: 40$ & 11 & $2 . \overline{7}$ \\
\hline 8 & 35 & T.U.R. & 30 & 1:50 & 10 & 3.0 \\
\hline 9 & 58 & Herniorrhaphy & 30 & $1: 40$ & 7 & 2.5 \\
\hline 10 & 22 & Appendectomy & 30 & $2: 10$ & 5 & 3.0 \\
\hline 11 & 19 & Appendectorny & 55 & $2: 20$ & 3 & 2.7 \\
\hline 12 & 25 & Removal of $\mathrm{rt}$. testis & 35 & $1: 30$ & 12 & 3.0 \\
\hline 13 & 43 & Appendectomy & 50 & $2: 10$ & 12 & 3.0 \\
\hline 14 & 19 & Madlener's operation & 25 & $2: 10$ & 4 & 2.8 \\
\hline 15 & 35 & Simple hysterectomy & 40 & $2: 40$ & 6 & 2.6 \\
\hline 16 & 22 & Caesarean section & 35 & $2: 20$ & 7 & 2.5 \\
\hline 17 & 26 & Simple hysterectomy & 40 & $2: 40$ & 6 & 2.5 \\
\hline 18 & 52 & Haemorrhoidectomy & 25 & $1: 40$ & 8 & 2.5 \\
\hline 19 & 33 & Appendectomy & 30 & $1: 20$ & 6 & 2.7 \\
\hline 20 & 17 & Appendectomy & 25 & $1: 30$ & 7 & 2.6 \\
\hline Mean & 32.6 & & 34.8 & $1: 53$ & 7.4 & 2.64 \\
\hline
\end{tabular}

TABLE II

Patients and Operations for Spinal Anaesthesia with Lidocaine

\begin{tabular}{|c|c|c|c|c|c|c|}
\hline $\begin{array}{c}\text { Patient } \\
\text { no. }\end{array}$ & Age & Operation & $\begin{array}{l}\text { Operative } \\
\text { time } \\
\text { (min) }\end{array}$ & $\begin{array}{c}\text { Duration } \\
\text { of analgesia } \\
\text { (min) }\end{array}$ & $\begin{array}{l}\text { Level } \\
\text { (T) }\end{array}$ & Dose \\
\hline $\begin{array}{r}1 \\
2 \\
3 \\
4 \\
5 \\
6 \\
7 \\
8 \\
9 \\
10 \\
11 \\
12 \\
13 \\
14 \\
15 \\
16 \\
17 \\
18 \\
19 \\
20\end{array}$ & $\begin{array}{l}30 \\
41 \\
46 \\
26 \\
26 \\
21 \\
34 \\
28 \\
31 \\
23 \\
27 \\
28 \\
35 \\
16 \\
33 \\
16 \\
31 \\
21 \\
27 \\
37\end{array}$ & $\begin{array}{l}\text { Herniorrhaphy } \\
\text { Removal of Bartholine cyst } \\
\text { Removal of rt. testis } \\
\text { Simple hysterectomy } \\
\text { Herniorrhaphy } \\
\text { Appendectomy } \\
\text { Madlener's operation } \\
\text { Caesarean section } \\
\text { Appendectomy } \\
\text { Herniorrhaphy } \\
\text { Caesarean section } \\
\text { Madlener's operation } \\
\text { Appendectomy } \\
\text { Herniorrhaphy } \\
\text { Incision of It. knee region } \\
\text { Appendectomy } \\
\text { Herniorrhaphy } \\
\text { Herniorrhaphy } \\
\text { Appendectomy } \\
\text { Left oophorectomy }\end{array}$ & $\begin{array}{l}41 \\
50 \\
60 \\
48 \\
35 \\
20 \\
30 \\
40 \\
25 \\
25 \\
55 \\
30 \\
30 \\
20 \\
38 \\
25 \\
15 \\
25 \\
15 \\
40\end{array}$ & $\begin{array}{l}1: 30 \\
1: 50 \\
1: 50 \\
2: 50 \\
2: 10 \\
1: 40 \\
1: 50 \\
2: 40 \\
2: 20 \\
1: 40 \\
2: 20 \\
1: 40 \\
1: 40 \\
1: 20 \\
1: 40 \\
1: 20 \\
1: 30 \\
2: 00 \\
2: 10 \\
1: 50\end{array}$ & $\begin{array}{r}5 \\
11 \\
8 \\
8 \\
11 \\
7 \\
7 \\
5 \\
6 \\
8 \\
6 \\
7 \\
8 \\
6 \\
8 \\
10 \\
12 \\
10 \\
9 \\
8\end{array}$ & $\begin{array}{l}2.5 \\
2.0 \\
2.6 \\
3.0 \\
2.5 \\
2.2 \\
3.5 \\
3.0 \\
2.3 \\
2.5 \\
2.5 \\
2.5 \\
2.5 \\
2.3 \\
2.5 \\
2.5 \\
3.5 \\
2.6 \\
2.5 \\
2.5\end{array}$ \\
\hline Mean & 28.8 & & 33.5 & $1: 54$ & 8.0 & 2.65 \\
\hline
\end{tabular}


<smiles>CCCNC(C)(C)C(=O)Nc1ccccc1C</smiles><smiles>CCN(C)CC(=O)Nc1c(C)cccc1C</smiles>

Ficure 1. Chemical structures of quatacain and lidocaine.

groups was 1 hour 53 minutes and 1 hour 54 minutes respectively. The mean analgesic levels in the two groups were $\mathrm{\tau} 7$ and $\mathrm{\tau} 8$ respectively, and the average operating time was 34.8 and 33.5 minutes respectively. The level of analgesia was checked by pinprick. The analgesic time was designated as the time between the start of injection of the agent and the disappearance of analgesia over right $\mathrm{L} 5$ region; this was checked every 10 minutes. The free cortisol (17-hydroxycorticosteroid $=17-\mathrm{oHCS}=$ hydrocortisone $)$ in $1.0 \mathrm{ml}$ of plasma was determined according to the method of Rudd ${ }^{10}$ with a Farrand spectrofluorometer. The duplicate error of our method was $\pm 1.2 \mu \mathrm{g}$ per $100 \mathrm{ml}$ of plasma, which appeared to be reliable for the analysis of our data.

The blood sampling times were as follows: (1) in the afternoon 10 minutes before the start of spinal anaesthesia; (2) 10 minutes after the start of anaesthesia before surgery; (3) 15 minutes after the start of surgery; and (4) $3 \%$ hours after the start of spinal anaesthesia. Three millilitres of venous blood were obtained in a heparinized syringe, and centrifuged within 30 minutes.

\section{RESULTS}

1. Mean plasma cortisol levels in the seven control patients is shown in Table III. The level was $8.9 \pm 1.2 \mu \mathrm{g} / 100 \mathrm{ml}$ ( $\pm=$ standard error of the mean) at $2 \mathrm{PM}$; it changed to $9.4 \pm 1.3,9.9 \pm 0.5$, and $9.3 \pm 1.0 \mu \mathrm{g} / 100 \mathrm{ml}$ at $2: 30,3: 00$, and 6:00 PM respectively.

2. The mean plasma cortisol level in the quatacain group just prior to start of spinal anaesthesia was $14.0 \pm 1.6 \mu \mathrm{g} / 100 \mathrm{ml}$. It decreased slightly and insignificantly to $13.3 \pm 1.5 \mu \mathrm{g}$ during 10 minutes of "held" spinal anaesthesia. However, it significantly rose $(p=0.007)$ to $17.9 \pm 0.4 \mu \mathrm{g}$ at 15 minutes after the start of surgery, in comparison with the control prespinal level shown in Table IV and Figure 2. The mean plasma free cortisol level was $16.3 \pm 2.3 \mu \mathrm{g} 3 \%$ hours after the start of spinal anaesthesia; it did not show a statistically significant difference from the control prespinal level. 
OYAMA \& MATSUKI: PLASMA LEVELS OF CORTISOL IN MAN

TABLE III

Plasma Levels of Cortisol $(\mu \mathrm{g} / 100 \mathrm{ml})$ in Control Group

\begin{tabular}{lcccc}
\hline $\begin{array}{c}\text { Patient } \\
\text { no. }\end{array}$ & $\begin{array}{c}2: 00 \\
\text { PM }\end{array}$ & $\begin{array}{c}2: 30 \\
\text { PM }\end{array}$ & $\begin{array}{c}3: 00 \\
\text { PM }\end{array}$ & $\begin{array}{c}6: 00 \\
\text { PM }\end{array}$ \\
\hline 1 & 7.0 & 11.0 & 12.0 & 10.0 \\
2 & 8.0 & 8.0 & 7.0 & 4.0 \\
3 & 12.0 & 15.0 & 11.0 & 11.0 \\
4 & 14.0 & 9.0 & 9.0 & 5.0 \\
5 & 11.0 & 13.0 & 17.0 & 10.0 \\
6 & 5.0 & 5.0 & 7.0 & 6.0 \\
7 & 5.0 & 5.0 & 6.0 & 5.0 \\
Mean & 8.86 & 9.43 & 9.86 & 7.29 \\
S.E. & 1.24 & 1.34 & 1.35 & 1.02 \\
p & & 0.625 & 0.511 & 0.329 \\
\hline
\end{tabular}

TABLE IV

Plasma levels of Cortisol in Man during Spinal anaesthesia WITH QuATACaIN AND SURGERY $(\mu \mathrm{g} / 100 \mathrm{ml})$

\begin{tabular}{rrrrr}
\hline $\begin{array}{c}\text { Patient } \\
\text { no. }\end{array}$ & Prespinal & $\begin{array}{c}\text { Spinal } \\
10 \mathrm{~min}\end{array}$ & $\begin{array}{c}\text { Op. } \\
15 \mathrm{~min}\end{array}$ & $\begin{array}{r}\text { Spinal } \\
3 \frac{1}{2} \mathrm{hrs}\end{array}$ \\
\hline 1 & 33.0 & 20.0 & 24.5 & 24.0 \\
2 & 17.0 & 20.0 & 25.0 & 28.0 \\
3 & 16.0 & 20.0 & 24.0 & 12.0 \\
4 & 10.0 & 14.0 & 22.0 & 8.0 \\
5 & 15.0 & 17.0 & 15.0 & 13.0 \\
6 & 10.0 & 14.0 & 22.0 & 8.0 \\
7 & 10.0 & 4.0 & 20.0 & 35.0 \\
8 & 25.0 & 25.0 & 18.0 & 40.0 \\
9 & 13.0 & 8.0 & 11.0 & 8.0 \\
10 & 8.0 & 8.0 & 16.0 & 18.0 \\
11 & 15.0 & 10.0 & 15.0 & 12.0 \\
12 & 15.0 & 10.0 & 15.0 & 12.0 \\
13 & 6.5 & 5.5 & 8.5 & 6.5 \\
14 & 14.5 & 13.0 & 22.5 & -5 \\
15 & 5.0 & 7.5 & 10.0 & 10.5 \\
16 & 20.5 & 27.0 & 27.5 & 27.5 \\
17 & 21.5 & 18.0 & 29.0 & 16.0 \\
18 & 5.5 & 6.0 & 6.0 & 6.0 \\
19 & 7.5 & 11.5 & 15.0 & 16.5 \\
20 & 10.0 & 8.0 & 12.0 & 9.5 \\
Mean & 14.00 & 13.33 & 17.90 & 16.34 \\
S.E. & 1.57 & 1.45 & 1.43 & 2.23 \\
$p$ & & 0.515 & 0.007 & 0.994 \\
\hline
\end{tabular}

3. The mean plasma cortisol concentration in the lidocaine group just prior to start of spinal anaesthesia was $15.1 \pm 1.6 \mu \mathrm{g} / 100 \mathrm{ml}$, as shown in Table V and Figure 2. It fell insignificantly to $14.3 \pm 1.2 \mu \mathrm{g}$ at 10 minutes after "held" spinal anaesthesia. However, it rose significantly to $18.5 \pm 1.7 \mu \mathrm{g}(p=0.04) 15$ minutes after the start of surgery.

\section{Discussion}

The relatively high plasma cortisol levels in the surgical patients at $2 \mathrm{PM}$, just prior to start of spinal anaesthesia $(14.0-15.1 \mu \mathrm{g})$, in comparison with levels in the seven non-spinal subjects $(8.9 \mu \mathrm{g})$, appear due to preoperative emotional 


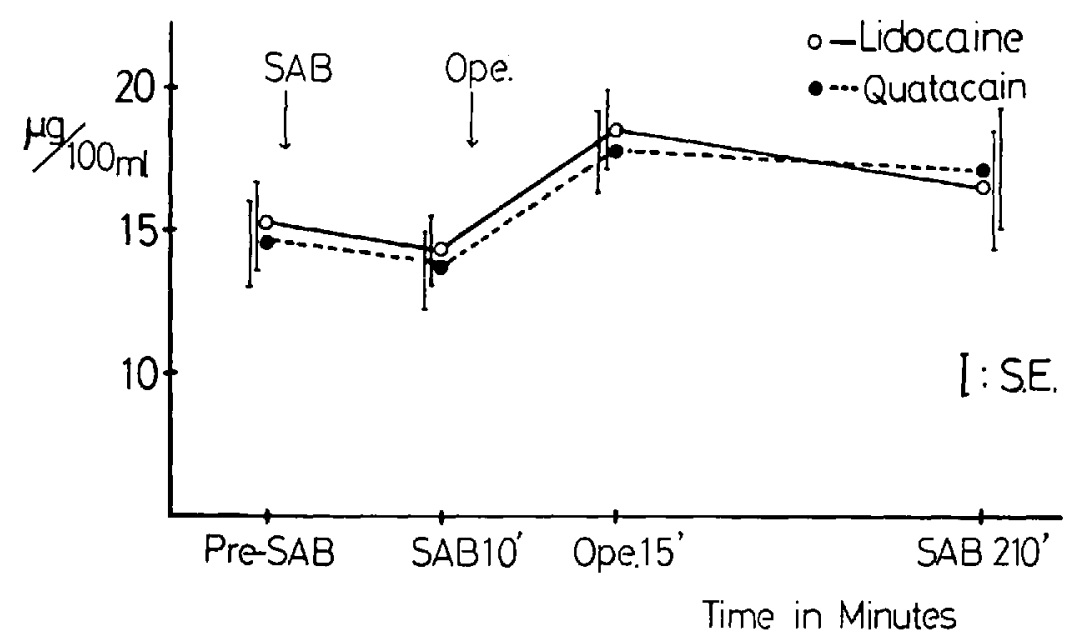

Figure 2. Plasma free cortisol levels during subarachnoid block and surgery in 40 patients.

stress in the absence of pre-anaesthetic medication, as demonstrated by us previously. ${ }^{11,12}$

As in other reports, ${ }^{1-4,13}$ no appreciable effects of spinal anaesthesia alone on plasma cortisol level were noted in either the quatacain or the lidocaine groups. In contrast to other reports, ${ }^{2-4}$ plasma cortisol concentration further significantly increased $(4.2-4.3 \mu \mathrm{g} / 100 \mathrm{ml}, p=0.001)$ when the surgical intervention was added to spinal anaesthesia, although the degree of plasma cortisol level elevation was less than that under ether or halothane anaesthesia as reported in the literature. ${ }^{1-7}$ Almost all cases in our study were minor operations such as appendectomy and herniorraphy, which might explain why the magnitude of elevation in plasma cortisol level was lower than in other operations under ether $(30.2 \mu \mathrm{g})$ or halothane anaesthesia $(26.3 \mu \mathrm{g})$ in our previous reported studies. ${ }^{5,6}$ It is known that the degree of adrenocortical response to stress is dependent upon the magnitude and the severity of the stress. ${ }^{1,4}$

Virtue and his associates ${ }^{2}$ studied 10 spinal cases with procaine. They found that spinal anaesthesia for one hour insignificantly increased plasma cortisol level $(2.7 \pm 2.1 \mu \mathrm{g} / 100 \mathrm{ml}$ ). Even one hour after the start of operation, the average increase in cortisol was $1.4 \pm 3.0 \mu \mathrm{g} / 100 \mathrm{ml}$. However, five patients in poor condition who had severe pulmonary emphysema, diabetes, and chronic nephritis were included in their series. Therefore, it is difficult to evaluate their results.

Hammond et $a .^{3}$ found no significant elevation in plasma cortisol level during operation under spinal anaesthesia in seven patients. They observed a marked rise in plasma cortisol level after the disappearance of the effect of spinal anaesthesia. However, Sandberg et al. ${ }^{1}$ who studied the influence of spinal anaesthesia on plasma cortisol level in four patients, found an elevation of plasma cortisol level by spinal anaesthesia from $13.5 \mu \mathrm{g}$ of prespinal mean value to $16.7 \mu \mathrm{g}$ after the start of spinal anaesthesia, and it increased further to $26 \mu \mathrm{g}$ postoperatively.

Not all past reporters analysed their data statistically. We failed to detect a 
TABLE V

Plasma Levels of Cortisol in Man during Spinal Anaesthesia WITH LIDOCAINE AND SURGERY $(\mu \mathrm{g} / 100 \mathrm{ml})$

\begin{tabular}{rcccc}
\hline \hline $\begin{array}{c}\text { Patient } \\
\text { no. }\end{array}$ & Prespinal & $\begin{array}{c}\text { Spinal } \\
10 \mathrm{~min}\end{array}$ & $\begin{array}{c}\text { Op. } \\
15 \mathrm{~min}\end{array}$ & $\begin{array}{c}\text { Spinal } \\
3 \frac{1}{2} \mathrm{hrs}\end{array}$ \\
\hline 1 & 18.0 & 20.0 & 24.0 & 24.5 \\
2 & 22.5 & 20.0 & 24.0 & 22.0 \\
3 & 16.0 & 20.0 & 12.0 & 24.0 \\
4 & 23.0 & 18.0 & 26.0 & 15.0 \\
5 & 30.0 & 20.0 & 15.0 & 30.0 \\
6 & 10 & 14.3 & 10.5 & 16.8 \\
7 & 10.5 & 8.0 & 10.5 & 6.5 \\
8 & 24.0 & 20.0 & 30.5 & 40.0 \\
9 & 21.5 & 20.0 & 20.0 & 12.0 \\
10 & 14.0 & 8.0 & 20.0 & 20.0 \\
11 & 20.0 & 23.0 & 33.5 & 26.5 \\
12 & 12.0 & 10.5 & 17.5 & 6.5 \\
13 & 8.0 & 8.0 & 6.5 & 6.5 \\
14 & 9.0 & 8.5 & 21.5 & 3.0 \\
15 & 13.0 & 10.0 & 10.0 & 7.0 \\
16 & 4.5 & 10.0 & 10.0 & 14.5 \\
17 & 14.5 & 14.5 & 17.0 & 17.0 \\
18 & 3.5 & 10.0 & 11.5 & 13.5 \\
19 & 11.5 & 11.5 & 23.5 & 15.0 \\
20 & 12.0 & 11.0 & 15.5 & 14.0 \\
Mean & 15.13 & 14.26 & 18.50 & 16.71 \\
SE & 1.57 & 1.21 & 1.70 & 2.11 \\
p & & 0.359 & 0.041 & 0.341 \\
\hline
\end{tabular}

statistically significant alteration in peripheral cortisol levels during anaesthesia alone; but a significant increase of cortisol was observed during operation, although the magnitude of elevation was within the upper limit of normal range.

All reports of the effect of spinal anaesthesia on adrenal function, judging from peripheral blood levels of cortisol, indicate that adequate spinal anaesthesia prevents adrenocortical stimulation. ${ }^{2-4}$ According to these reports, when the effect of the nerve block disappeared the adrenocortical response to surgery became apparent. In those cases where an elevation in circulating cortisol had been detected during spinal anaesthesia, either anaesthesia had not attained a sufficient level or the rises in blood levels of cortisol were not very significant. Relatively lower levels of spinal anaesthesia ( $\mathrm{T}$ 7-8) in our series than in Hammond's study ( $x$ 5.5), shorter duration of our spinal anaesthesia alone (10 minutes) than in other series which held for at least one hour, ${ }^{2,3}$ and shorter duration of sampling time during operation ( 15 minutes as against one to two hours) might account for the difference between our results and others. ${ }^{3}$

The increased plasma levels of cortisol during surgery are interpreted as due to afferent nerve impulses arising from the operative site ${ }^{13}$ It has been speculated that spinal anaesthesia can prevent the normal response by blocking the afferent sensory system from the injured area. ${ }^{2,3}$ However, it should be mentioned that emotional stress causes a rise in plasma cortisol level just prior to the induction of anaesthesia. ${ }^{11,12}$ Therefore, even under adequate spinal anaesthesia, the patient's emotional stress cannot be prevented by this technique during operation. This phenomenon might be responsible for the observed significant preoperative 
elevation of plasma cortisol level in our study. From the clinical point of view our findings would suggest that spinal anaesthesia even to an adequate level does not necessarily block adrenocortical activity. Therefore, it is not always the technique of choice for those patients with hyperadrenocortical function such as Cushing's syndrome and aldosteronism.

\section{Summary and Conclusions}

Plasma free cortisol levels were measured in 47 patients. Seven patients served as a control group. Twenty patients received spinal anaesthesia with the newly synthetized short-acting quatacain (Tanacaine), and the remaining 20 underwent spinal anaesthesia with lidocaine (Xylocaine). There was no significant influence on the plasma free cortisol levels in the 40 patients during spinal anaesthesia before operation. However, plasma cortisol increased significantly during operation, although the magnitude of the elevation was less than during general anaesthesia.

\section{Résumét}

Nous avons mesuré, chez 47 malades, les taux de cortisol plasmatique libre. Sept malades ont servi de groupe témoin. Vingt malades ont reçu une rachianesthésie avec le nouvel agent synthétique à action courte: quatacaine (Tanacaine) et les vingt autres ont eu une rachianesthésie avec de la lidocaïne (Xylocaine). Avant l'opération, nous n'avons pas observé de modification importante des taux de cortisol plasmatique libre chez les quarante malades sous rachianesthésie. Pendant l'opération, toutefois, le cortisol plasmatique a augmenté de façon appréciable. Toutefois, l'importance de l'augmentation du taux de cortisol plasmatique est demeurée inférieure à celle observée au cours de l'anesthésie générale.

\section{REFERENCES}

1. Sandberg, A. A.; Ex-Nes, K.; Samuels, L. T.; \& Tyler, F. H. The Effects of Surgery on the Blood Levels and Metabolism of 17-Hydroxycorticosteroids. J. Clin. Invest. 33: 1509 (1954).

2. Viatue, R. W.; Helmaeich, M. L.; \& Gainza, E. The Adrenal Cortical Response to Surgery: I. the Effect of Anesthesia on Plasma 17-Hydrocorticosteroid Levels. Surgery. 41: 549 (1957).

3. Hammond, W. G.; Vandam, L. D.; Davis, J. M.; Carter, R. D.; Ball, M. R.; \& Moore, F. D. Studies in Surgical Endocrinology: IV. Anesthetic Agents as Stimuli to Change in Corticosteroids and Metabolism. Ann. Surg. 148: 199 (1958).

4. VANDAM, L. D. \& Moore, F. D. Adrenocortical Mechanisms Related to Anesthesia. Anesthesiology. 21: 531 (1960).

5. Oyama, T.; Sarto, T.; Isomatsu, T.; Samejima, N.; Uemura, T.; \& Armura, A. Plasma Levels of ACTH and Cortisol in Man during Diethyl Ether Anesthesia and Surgery. Anesthesiology. 29: 559 (1968).

6. Oyama, T.; Shmata, S.; Matsumoto, F.; Takiguch, M.; \& Kudo, T. Effects of Halothane Anaesthesia and Surgery on Adrenocortical Function in Man. Canad. Anaesth. Soc. J. 15: 258 (1968).

7. Oyama, T.; Shibata, S.; Matsumoto, F.; Matsukr, A.; Kimura, K; Takazawa, T.; \& KuDo, T. Adrenocortical Function Related to Methoxyflurane Anaesthesia and Surgery in Man. Canad. Anaesth. Soc. J. 15: 362 (1968).

8. Oyama, T. \& TAkiguchi, M. Effect of Neuroleptic Anaesthesia on Adrenocortical Function in Man. Brit. J. Anaesth. (In press.) 
9. Oyama, T.; Kmura, K.; Takiguchi, M.; Tamazawa, T.; \& Shlbata, S. Effects of Propanidid on Adrenocortical Function in Man. Anesth. \& Analg. In press.)

10. Rudd, B. T.; Sampson, P.; \& Brooke, N. A New Flurometric Method of Plasma Cortisol Assay with a Study of Pituitary-adrenal Function Using Metyrapone (su 4885). J. Endocrin. 27: 317 (1963).

11. Oyama, T.; Kimura, K.; Takazawa, T.; \& Takiguchi, M. An Objective Evaluation of Tranquillizers as Preanaesthetic Medication: Effect on Adrenocortical Function. Canad. Anaesth. Soc. J. 16: 209 (1969).

12. Oyama, T.; Shibata, S.; Kimura, K.; \& Takazawa, T. Objective Evaluation of Pentobarbital as Preanesthetic Medication: Effect on Adrenocortical Function. Anesth. \& Analg. 48: 367 (1969).

13. Greene, N. M. Physiology of Spinal Anesthesia. 2nd ed., Baltimore: Williams \& Wilkins (1969). 